\title{
Trust in Subcontracting Relations between the Large Enterprises and Small-Medium Enterprises in Korea: With Implications for Economic Development
}

\author{
HALRAN LIM

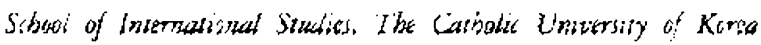

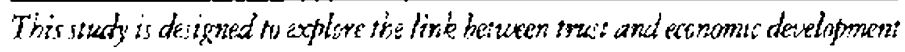
b) forwing on ine siamirating whation beticen the lange entertwiter (LE) and the small and meitum entoprises (SMEs) in Korka. In this simd:

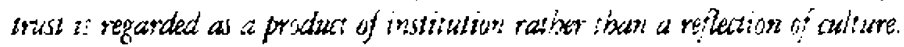

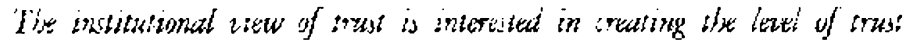

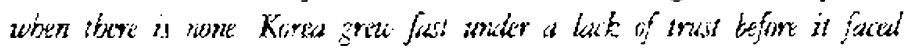

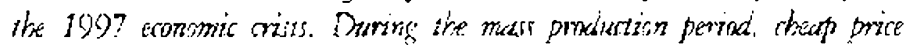

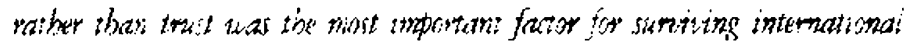

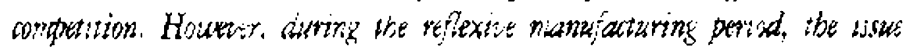

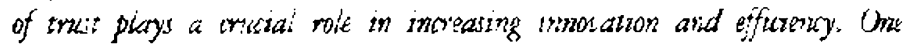

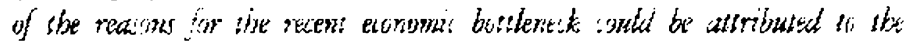

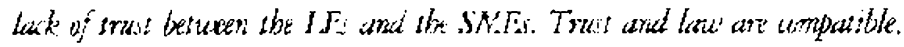
and the Latter max; rontribute ts developing and strengthening the formur.

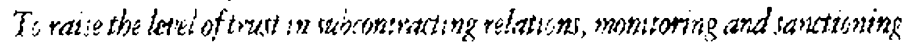

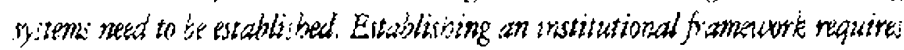
a genuine interest match amons the goternment, the LE; and the 5 MEs.

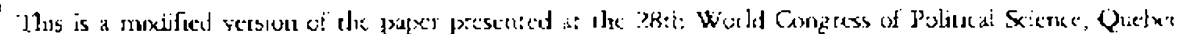

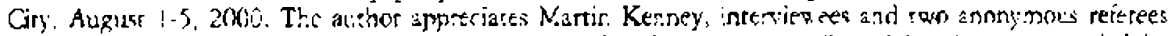

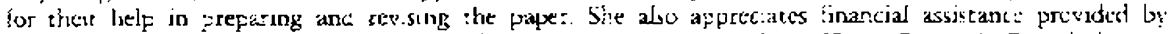

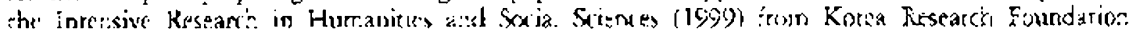
Direct a! correspcndence te Hatran Lim Pectesse: of internaticnal studies, Cathol:c lenversiny .) Kirta

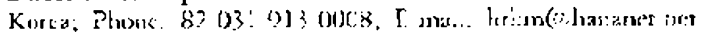




\section{INIKODUCIION}

$\mathrm{R}$ exeritly, a great deal of literatiee has appeared aralyuing the relationslop lecween

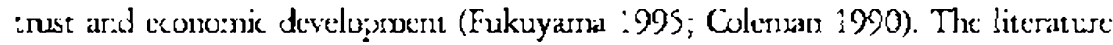
ercats trust as an important facor that could explain why some cumntrics develop? while others 'ag behind, and of:en concludes that societies with a high level of trust grow faster and those with a lew ievel of trust grow slower anc have a tendency to experience political instaibility.

A problem witr. these studies is that they take a static view: they compare developed countr:es and lesi developed countries and explain the contrast by the different ievels of tuscr. This approuth has merit by cearrying out a cross level-comparative analysis. BLt it has difficu'ties in explaining a dyounuc chang: over tine; why has a country grown rapidly for some tines and there turnbled ciown at a ate: time? If we are to

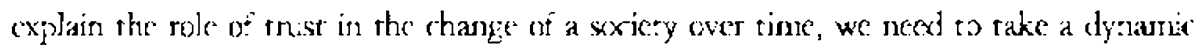
opproach anc fones on the var:arion of trust zela:ionships among main actors

Then are some studies that ake a cynamic approach to explain the rapid developonen: of Krirea. They renter on the relatiorship beiween the governmen: and the large enterprises (LEs) cver time (Evars 1995: E.M.Kim 1993; J.E.Woo 1991), and moscly conclude that puslic and private cooperation. i.e., the cooperation between the gcvernment and the LLs, was a main sactor for rapic economic growth (Onis 1991). licwever, focusing on the rratual interest between the governencret and the Llis ends to ignore the role of :he private seceror in Koreas development, and deesn't fully explain

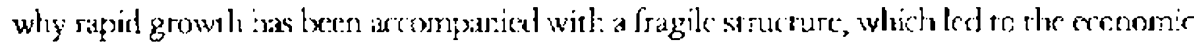
crisis.

To Lnderstand the stnirtural botrienecks in the Korean economy, we need to examine the in:erest elationship arrong privare aciors along with the cooxtration. between pujlic and private ac:ors. Such a relationship is best represented by the subcontracting relationshp benween the LEs and the small-mecium en:erprsses (SMEs). Empirical stidies of the link beeween emust and economic developmert, focusing on subcontracting relaticis have multiplied in indistr:alized countrics such as Japin, the Uniced States and the Eurcpean countries (Gambrica 1)88; La:e and Bathmann 19)8). I lewever, empirical stucies of sulxontracting eclesions ir. Korca arc rare. Mhis study will fixus

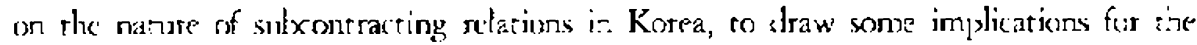
mie of trisst in eroromic cevcoprent and crisis

Truse may $x$ seen as a by-product of cilture or as a produce of institution. If se regarc trist as a producr cf culture, we coutd suppose that culture, as a source of tnust, does no: change rapidly. In this caie then, we could rot explain the :rarsformat:ve process of economic development and crisis over turne with low or ne variation in culture. Also, if we sec enst as a reflection of cultuet, it may be difficult 10 creace

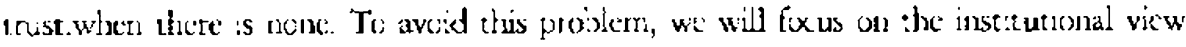
of trist, which is interestex: in crearirg a lewel of trast when there is nons.

What makes the researci question :mzaling is that the ana.ysis of tmust in sib- 
contracting relations setms to tace an ironic phenomenon: Korea experienced ast growth under a ark of trus: in the sulxonuracing system betore it faced an economic crisis. Tays stucy attempts to expian how a ow level of erust affects comame pertornarke during the transiormative periax of capitialist production ard sigenests some poss ble ways to build tonest.

The remairing of this paper is organized as follows. The next section critically reviewx various perspectives of rust and suggests a theoretical framework for this study. The third section examines the empirical case of Ko:ea, focusirg on the subcontacting relationship betheer. the LEs and the SMEs to exploie the effect of cnust on economic development. The fouric secrion sliggesss several ways of building trust thrcingh which wh uncocperative subcontracting relatonshup car: be transtonod into a coupcrative o:e. The final section comcludes with a briet sumunary and some comments.

\section{THEORETICAL FRAMEWORK}

\section{Concept and Origin of Trust}

Trust ptovides a way :o cope wich risk et unceraincy in exchange relatiorships. Risk

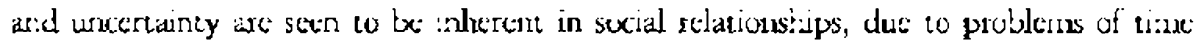
and information. Trust, therefore, is a methanism, which cvercomes the problem of rias and bridges uncerainty in the Gace of imperfect informatior. Nlso, rnuss is a mertanism by which artors redure the in:ernal complexiry of rheir system of ir.terartion (I.uthann :989). Various definitions of :nust have :wo core elements: an agenc's acceptance of risk trom the actions of crhers; aad the expectation that the partner will no: take advantage of the opporiunities opened up by the agent's acceptance of tisk. Inust is vieweci as accepted ralnerability to another's possible but not expectec ill-wil towarc vae.

One nay argue talat the differeat evels of trist annong various societies could be

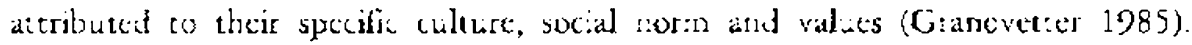
liukuyama (:905) argues that enust comes frum shared values, and norme, and believes that eronomit acters suppert cach other winen they share a community of trist. Fo:kuyama suggests cross-cultural cifferences in socia, capiral to expain cross-rational differences in forms of ecoromic crgarization. He connecrs a high leve of trust with development and a lon level of trust wita underdevelopment.

Some schciars claim that Confuciarusm has functioned as an important cult:ure for fistering :rust and cooperation in Last Asia, especially in Korea (S.C.Lew 1997; M. H.Kook 1997). According te S.C.lew (:997), ene ethics asd cudeure of Confuciasism indluenced Korean sucicty so moill that the sociai ties such as fanily, schoo', and region functenced as an impertant Jasis of netwerks in society. The exisrence of social nerworks decreaser. the transartion costs of cyonon:or and social antivities, thesefore contributing to economic devclopment in Korea. Lew also argucs that there was 
limited predatory behavior urder the extens:ve use of social networks. Alt:ough liukuyama and Lew disagree with the ssue of whethet Confucianism fosters truse or not, tixy are in agrexment with the dea that toust is a by prexluc: of culturs.

Itowever, the cultiral exerspective of trust seems to inclube several problems. First, if :nss: is secs as a reflection of cr.lture, sxieries without tr.ast are donmed on suffer from the aegarive effecrs of low trust, and it may seem tifficalt then to create trist in suca ar, erviroament. However, empicrical work tells us that tr.sst can be buil: even between people from. different cultural backgro'ands cr between indwiduals who share no values beyond their narrow bus:ness goals (Lane and Bacnmann 19y)8). Seccond, if we suppose that culture dox's no: change tapidly, it may be dificult to rejare the rapid trarstormative process of cononic development with: slow caltural change.

Yarragishi, Coxk and Watabe (1998) unducted a cross socieral exporimentarion to wempare the level and crigin of trust an Japan ard the United Sta:cs Accordisy to a simplist: view of culture (the incividialistic view), Japranese people prefer to be part of a group ard they are by nat:are collertivists, while Americars are more indivitua'ist ar.d value independence :roro the group. Contrary to this simplistic view of American ard Japarese culture, the results of their experiment showed thas tine tendeacy to :emain in a grolip aias much strorger among Americans than among the Jananese.

This paradoxical resut can be explained using the institurional view of trust. Acco:dirg to this view, the Japariese often preter to belong to groups and place group interests above treir own individual inseress not xecause they it:trinsically like to do

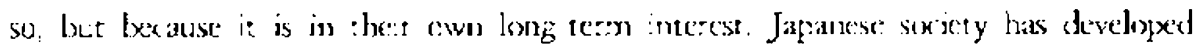
systems of rrutual moriroting and sarctoning 20 clertail frep-riding in a collective

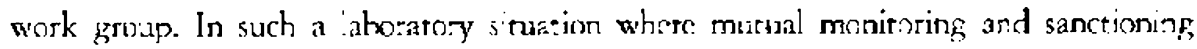
do no: exist, Japanese :enc. to prefer at to stay in the group. Yamagish.'s (:988) cross-societal experiments also show that oace oprortunities for monitoring and sanctionirg are emovec, the Japanese arc in tact less cooperative in arnicving gro:lp goals than a:e Americars. External scisal control is srreng in collectivistic Jajanese society, where motuci montormg and saxcioning are exerted through fertings of shanke. However, an internal guilty lecling is enore imporzance is: an indivesualistic Anserican soxiety. From these experinexts, we find out that the cultural clifference disalpears once these fartors ane exporimentally controiled

Kim ard Son (1998) replinated Yamagis's's experiment (1988) in Korcu and showed that sancions were an important acto: in inducing cooperation in Korear.s ar.d the Japanese. In general American students had the highest eve.s of trist, whiz Koreans and Japanese were similar in terms of ow level of trisc. The introducticn of sancrions induced non-conjerators to cocperate, especialy in Korea and Japan. However, the level of cooperation may drop when the sanctioning systerr: is withdrawn.

The institutionalisic view regards instivution suth as sancioning as an inportant basis for trust. ilowever, when we rely aightly on sanctions to induce roperation, woperation will sudden y dirop if the system of sarctions collapses die to governmenr failure. The :nstiouriuna view of trist is interested ir. crearing a general level of trist 
when there is none. It could explasn winy individial social actors are more inclined to rase cach other under the conditions of a certain institutiona environment, why they tend to distr.ast one another ir other circurstances, and low trist is cteatcd and reproctuced through various ins:ifutuonal ouders. Since Ko:can society is gencrally cha racterzed as one with a low level of mest, this study rakes the instimutional view of trust and explores the irstitutional mectianisms through which must could be huilt and maintained.

\section{Linkage betueen Trust and Ecomomic Development}

The link bewween trist and eco:1omic development cas: be analyzed through a macro persperive, focusing un system :aust, or through a micro perspective, narrowing

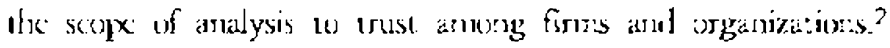

Macro analysis is interested in explaining how the str.icture of socicty affects econcmic pertormance. Gamberta's stuciy ot the Mafin in Iraly shcws us this perspective well (:989). Menhers of society are forced to choxse certain types of activities between reat seeking anc investmen: for competitiveness. Pecole are inclined to behave in a rational way not to be exciuded by the struciure (Lee, Jat-Hydk 1998). To choose to obialr. Mafia protecion car hardly be consicered itzational from an individial perspective. From these individually rational prerrises, though the collective disasters such as lower incentives for echno:ogical innovation and pourer quality of goods and services are likely w follow (Gamldsta 1988, 173). Thus, ra:ional individual behawior (and give rist to :rational cononic incfirieny, and prope's rent-serking activities are related to a lack of erust in the geverement. Rose (1998) a so explains how Russians use in iorral social nerworks to insulate themselies rom exploiarive naganizarions. They debureaucratize their relaticrs, rely:ng on personal corracts, Jareer or bribes. There is ar. absence of credib.e or effective systems of iustice and law enforcement, and pecple do not twist the government.

Studes of Korea also siow that tine structure of surety alfects cxoromic perlormance through its cefexe on puthlic and provate trast: a high leve. of public trust is associated

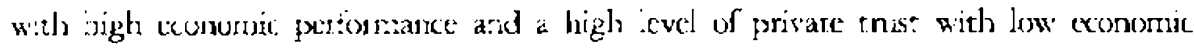

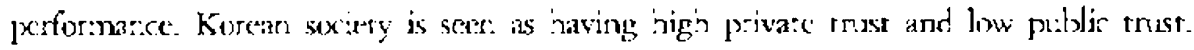
High private trist resides in the netwisks of :arily, showl, and region. Sirong trust exists wizin the boundaries of persona ties. The level of trust, however, is very tow oursice of thesc close ries and networks. In Korea, exclusive private ties between the government and thotbol created rents. Ratioring foreign exchange, restricting entry through : :censing producers, and tarifts or quartita:ive estrictions on imports were hays of creating etents, High returns from difectly urproductive protit-sceiking altivitues

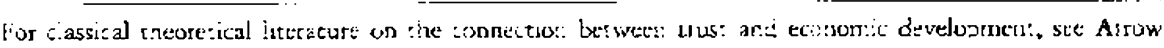
(19i;) a:cd Hikulama (1955!.

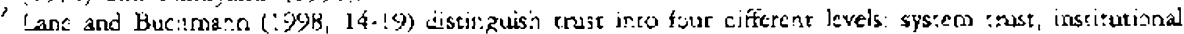

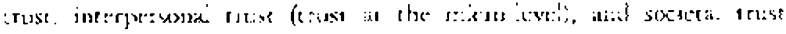


dominated productive activities, ans economic elfictency and dynamism declined, ${ }^{3}$ The exclusive ties between the government and the chaciol resulted in stricural corrupuion, with led 10 : he recent economuc crisis. 'The existence of rent-serking activities is likely to produce priblic distrust of the goverument. In suct: a saciety, people co not believe in law and government; :ather they ry to gain safeguards by bililding personal networks and relyirg on bribes.

However, a marro-analysis fails to expiain the causal 'ink between trust anc econonic development over time. From a marro perspective, we can expect trat high econonic performance is associatec with high public trust and low tconomic performance with high private trust. But as wa saw, government-business retworks in Korca tunctioned wcll in inducing economic efficiency for surete t:me, but sor tor onher tines, We

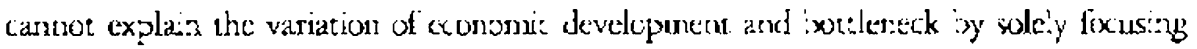
on a :arcro 'cre! of toist.

Auctler way of analyzing the connextion between trust and cronomic develoument is to forl:s on trust xitain and berween crganizations through a micro perspective. More specifically, we can explore the impact of truse among, Arros, especially between scoppliess anc customers, and on business performance. Sako (1998) asgues that interorganizational thist may eniance business perormance ir. a few ways: first, trust could reduce transaction costs; second building trus: in itself is an investmer.:; and thitd, trust gives rise to more apid in:movation and learning. Giranovetter (:985) a so argues that a high level of :rust te:noves the need for any contractual and monitoring devices, therefore reducing transartion uxis. A high level of trast makes it jessionte for exclyange pattners to state information. An casy excarge of information naxes them more open to eacin other, which inclines them to cxplore new opportunities for rolatararan, such as the impovernert of product cualiry.

Let s examine the Korean case. The cifficulty of exp.oring the empisical lirix berween system trust anc economic developmenc le: us to stucy the leve. of :nust berween organizations, especially trust in subcontwacting rela:ions between the LEs and the SNEs in Korea Korea passed through a rafizd growth perrod and then faced ar: exonomice crsis. The analysis of trus: in subcureracting relations alsc secms to face an iroric phenemenon: How did Kurea grow fast urde: a lack of trist in subcontraing reiations? Oxue explanation is that euring the mass protiction period, chap price was the most importan: factor in compering interrationally. Therefore, :nist was not a principal :ssuc, and the exploitative subcontracting elationship was litilized by custnmers to push coses dowr.

However, as the econcmy grew more sophisticated, trust in sujcontracting relations became prominent. Whereas the Fordis: production system is charactetized by producerdiven manufaciuring, the refexive rranutactur:ng sys:em is regardeci as demand-

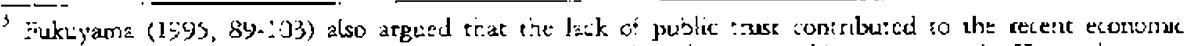

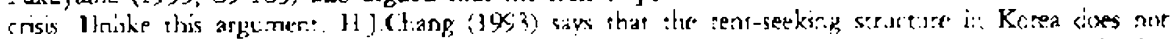
recessan'y lead to sxciai zas:e by divereing entreprereuriai activities from procuctive activit cs co unproductive uneseces, like lul:iyings.
} 
driven manufacturing (Hamiltor. 1999), ${ }^{4}$ In the flexible specialization period, the rature of demanci becomes more sophis:icated and pluraljzed. To respond to rapilly changing demands, firms necc: to be flexible ard swit:. Ihis :ype of manufacturing recuures backwand engwering, in which tike coordination betwen merchandisess anc: sub contractors, and tris: among varicis fems, hecome important. Since the 1980s, the Korean exanomy taced stuctiral obsacles due ti; the decteasing conperitiveness of firms based on the mass production system. The persistent exisinnce of exploitative relations beween tia LEs and the SMEs p:oducec strictural obstacles fo: ufgracing technological capabilities and concinuing innovation. The lack of tast in subcon:racting relations functioned as one o: the causes tor the recent economic crisis.

\section{SUBCONTRACTING RELATIONS BETWEEN THIE I.ES AND THE SMES IN KOREA}

To explore the lin' kerwen tmus and eronomic development, we need to discuss the characteristics of subcortracting relaticns in Karea. Before we discuss the natire of subcontrac:ing relations, let's first lock at the historical and political origins of this development of strong Lis and weak SMEs.

\section{The LEs and the Sillis in Koreas Gronth}

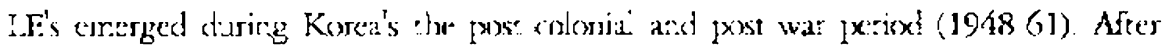
rolonization, former large scale Japanese industrial cacilies were sold to a few private enterprises at concessiorary prices. At the sume time, cistribution of American aid aftar the Knsean Wa: favored a few arge capitalists. However a spontaneous development of SME.s aiso emergec. The SMEs' share of Ko:ea's manufarturing employment and theirshare of manufacturing value iddod were 65.4 percent and 47.2 percent, respectively, in 1965 (lable ?).

Korea's ind ustral policy in the 1960s basically emphasized select:ve export promotion, and the finns involved in exports could rective state support. Selective export ptomotion: dis: wo: lenefit the SMLs, which we:e srouctura'ly domestic market oriented and weither equipped nor arpares for ex:orts (Regnicr 199?, 110). Although the IFs in those expurr-oriente: sectors wer more favored and the SMFEs were relatively disadvantaged, the policy tex se was hot argairst the SMEs. Although industrial policy in the 1960s did in fact favored the LEs over tire S.VEs, the main purpose of ixe policy was to promote expnts, and it dic no: peovice a policy base for the Les to taice over existing Silts.

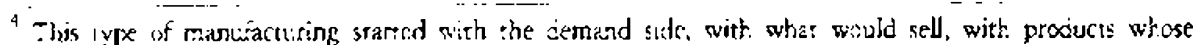

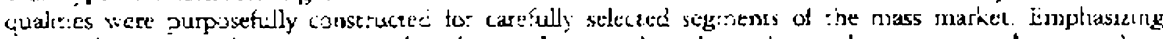

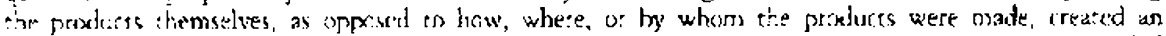

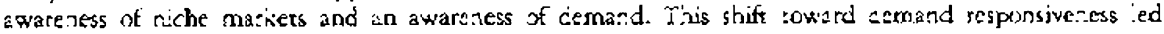

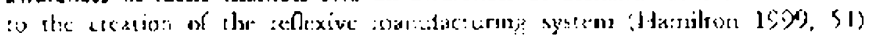




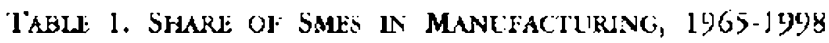

\begin{tabular}{|c|c|c|c|}
\hline Yeãr & Number of Firms & Enployees & Vaiue-added \\
\hline 1965 & 98.7 & 65.4 & 47.2 \\
\hline $19: 0$ & $97 . !$ & 49.0 & 28.5 \\
\hline $19 ? 5$ & 96.7 & 46.2 & $28 . \dot{i}$ \\
\hline 1980 & 26.6 & $4 ; x$ & $3>2$ \\
\hline 1985 & $9 ! 3$ & (5.1 & 37.6 \\
\hline 1300 & 98 & $6 . .7$ & 44 \\
\hline $1(x) 5$ & 9) & $6 \times 9$ & 16.5 \\
\hline
\end{tabular}

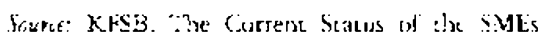

Hewever, during the 19-0s, the inclination of indistrial policy to favor [.Fs shrank the SUE; furthe:. Expont-led strategy led to the development of liarge assembiers by providing an incentive for them to inxort and thereby avoid the need to comestically produce parts and comporents. Export firms received various subsidies such as tax exemprions for importing jarts and components.

Durng the mud-1970s, Jarge asscrnbicrs ixgan to experience pressure to buy domestic pars and componen:s, and teicd to produce them internally and even took over small

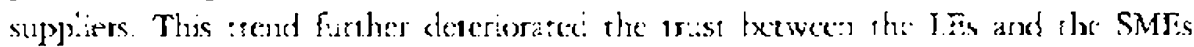

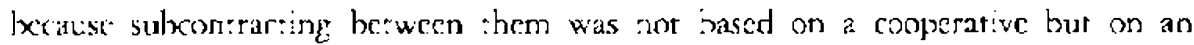
exploirative colatiorship. As a mechanism to promece their export-led srratregy, the Korean government established the General Tarding Comparies (GTC) in 1975. There were export subsidies and many privileges for the designated GTC Tuus the IEs began to build a vertical integraticn of production. by akking cver the SMLEs in o:der to become qualifed for the GIC, and sried to produce parts anc compcnen:s within then grol:ps. As a result, in the $-9 / 0 \mathrm{k}$, rany LEs eagerly took over the Swlis. as shown in Table 2.

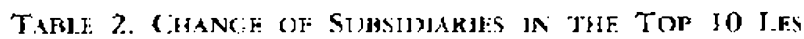

\begin{tabular}{|c|c|c|c|c|c|c|}
\hline Year & 64 & 65.69 & $701-74$ & $75-79$ & $80-84$ & $85-88$ \\
\hline $\begin{array}{c}\text { Establ:shment } \\
\text { Owcreaking } \\
\text { Sel: Off }\end{array}$ & $\begin{array}{c}17 \\
-4 \\
.\end{array}$ & $\begin{array}{r}23 \\
3 \\
.\end{array}$ & $\begin{array}{l}32 \\
19 \\
12\end{array}$ & $\begin{array}{l}40 \\
66 \\
12\end{array}$ & $\begin{array}{l}.9 \\
27 \\
49\end{array}$ & $\begin{array}{c}37 \\
6 \\
16\end{array}$ \\
\hline Subsidiares & 21 & 26 & $\therefore 9$ & 54 & -23 & 27 \\
\hline
\end{tabular}

Scure: Hor.g, iłng Pyn. 1993:45

lit the 16\%0s and early 1980s, he SMLE shers selves were no: willing to make an investment an the localizeitor: of parts and componerts for scveral reasons. First, foreign competitors such as, apanese parts makers lowered their costs wheneves Korean pars elippiers developed nox parts. Secondly, larg: assemblers in Korea did not wan: to buy parts andiaced by domestic makers. Finally, as mentioned above, the 
LEs in Korea merged domsstic parts inms into their sabsidiaries through vertical integratica.

As a result, the growtin of the SWFs was restra:nec and the number and the vaile added of the SMFs stagnanted. The SME share of Korea's manufacturing entployment dropped from 66.4 percent $\vdots 1965$ to 49.0 perces: in 1970 and then to 46.2 perceat in 1975. The SME share of manteacturing value adced dropped from 47.2 percent to 28.5 percent and thea to 28.0 in the sarat period (Tabie :).

Whilc SMEs dercriorated, lihere was a continued accuniulacion anc concentration ot the LEs during the period. Ovescas borrowing by the goveriment chanticled ptiotity loans :o tie Llis wits low intesest rates. Alsis there existed manly pronotion policies

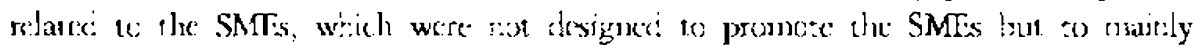
benefit the IEs, especialy throligh the con:rolled subentracting relationship. On the constrary, the SN'Es in Korea had limited access in snamcial Inans. The SMEs were competing for sunvival, and did no: have enough rescurces for collective action. 5 The Kcrean goverament did bot pay adequate attertion tc SA.Es: whereas it was sensitive to the problems of the LLs. The authotitaran government regime forced labor and the SMEs to bear the cosis of eccnomic adjistments.

In 1975, the governenent: cracted tine SME "Gyc-yul-twa" Ptomotivn Act. It was desigred to sirengelen and stabilize vertical relations betwoen large firms aed smaller

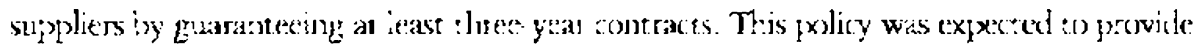
the S.MEs with a stable market. However, it resultest is hierarchical and tependent rhanaceristics of subcontracting telations hemise trusi herween the I.Es and the SMFs did not exist.

Whereas the earlie: economic period in Korea retlected the expansion of the LEs at the expense vit the SMEs, the per:od since the 11)80s shows the quantitative development of the SMLs. The subcontractirg rate of the SMEs nncreased diring the 1980s. Oux of total sales: subcontracting sales almos: doubled from 25.6 percent in 1980 to 46.6 percent in 1988. Wiketas the Llis stengetheace jts vertical integration of production by taking over SMFs and increasec in-house production ta the :970s, tix IFs have bern force! in increase subecontracting with the SMFs since the 1280s. The

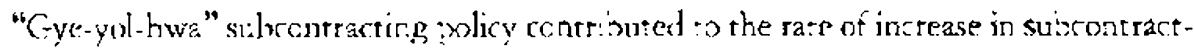
ing.

Chaebo: have zeer. forced to inc:ease their eliance on donestic sulxontzactors for ot.zer reasons besides this policy. Firsi, demand tor local supp.iers has increased as Koreas irdustrial production became nore advanzed anc sephusticated. Seconci, ever sirce :he proliferatw: of lator strixes in 198:, the chaeiol have been eaget wo shifi

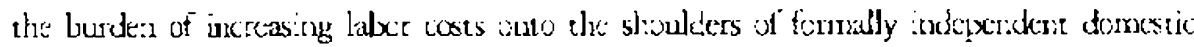

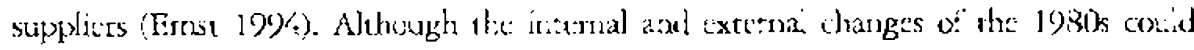

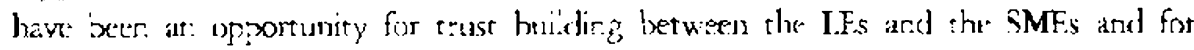

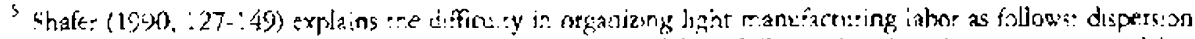

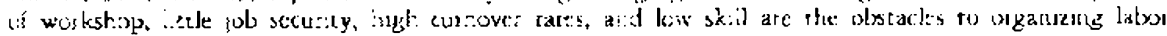

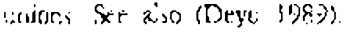


technological upprading anfair behavio: storts as susden-shifring by the LEs deteriorated rather tian improved relarionship.

In the 1980s, the trend of LE's ahsorbirg SMFs suppiers by the IFs has txen raduced somerhat. However, lEs did not provide the SMEs with a stáble matke: through trist, and dumping attacks by foreign firms as well as an insecure marke: for new producs still posed uostacles for the S.MEs to insest in innovarion of parts and components. This slakiky situano: gave rise to persistently weak and dependent SMLis.

Since the enc of the:980s, Korca's growt: has slowed. The primrary eauses lor the sluggish growth at the turn of the 1990s was awide work comesnic dowetetien, increased protectionism in. develnped rountries, less of price competitiveness due to rising wapes, ant weak tecinno igiral capabilit:es ir. various industrial sernors. The reasons for Korea's failure to deepen and upgrace its technolegical capabilities include lack of sophisticaticn, hig': cependence on imporeed parts and compenents, underceveloped abo: management and the lacs of trast and cooperation in subxoritracting telarionships. Ir. particular, the lack of trist was often considered the primary obsracle for firms to upgrade :bcie twhnological capabilitics.

Lavely, Kurea large assembless have realized the importance of a coopctative subcon-

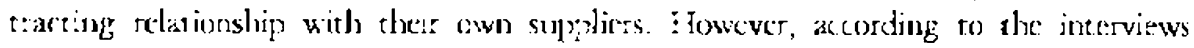
wirh several electrouics parts suppolicrs, it seems to be the case rlat large assemilers srill want to strengthen hera:chical and depencent relationships with subcortractors (Lin 1998)

I.ABLE 3. CCMPARUSON OF THE SMES IN MANUTACTLRING

\begin{tabular}{|c|c|c|c|}
\hline & Japar: ('97) & Triwan (97) & Kors:a ('98) \\
\hline Numiner of Tirms & 99.13 & 978 & 99.2 \\
\hline Number of Empioyees & -2.0 & 81.3 & 70.5 \\
\hline Valut-adjed & 55.2 & 34.4 & $\div 8.0$ \\
\hline Expctr & $\$ 1.8$ & SO).E & 39.6 \\
\hline
\end{tabular}

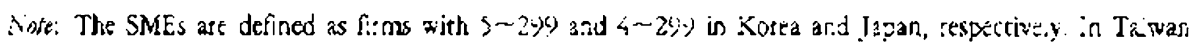

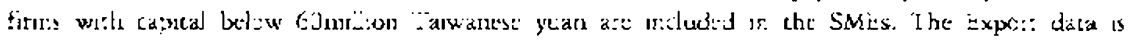
(x) : (9):

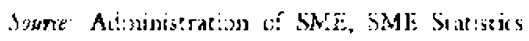

As Table 3 stows, the SMEs in Korea are characterzed as weak ard inferior in terms of the rumber of employees and the evel of preduction. Korean S.MEs Jag far hehind Taiwanese SMEs in the level of comperitiveness, represerted oy the percentage of exports. 'The contrasting industria structire between Korea and 'laiwan results in the different response to the recent economic crisis. Kerea's Lis-based structure, lacking trust with weak SMEs, eeflected exclusive bast of coalition that was urable to adjus: tothe rapidly clianging dimestic and internationsal envireoment. The SME-centered structure 
in lawan, however, basically shewed inclusiveness in its coalition base, and was there:ore flex:ble in adjusting to the clar:ging eavirument. Kerea and Taivan responded differently to similar internat ional challenges cue :o theit different comestic structures (I im 1999).

\section{Characteristics of Subcentracting Practices}

'The overall tread of subcontracting in Korea has been expansicnary, although it ras been stagnating in recen: years. Subxontracting rates have increased from 30.0 percent

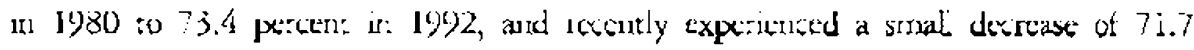
percent in 199: (Iable 4) I"1e "Gye-yol hwa" Promotion Act, was incencied to

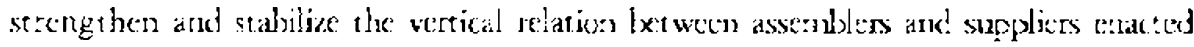
by the government in 1975, the numixer of designated sectors and produces initially increased from 6 and $7:$ in 1980 to 44 and 1553 in $: 984$, but has cecreased since 1985 (Table 5).

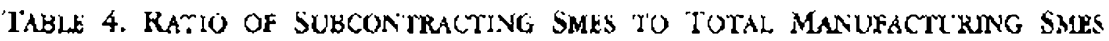

\begin{tabular}{|c|c|c|c|c|c|c|}
\hline & Bu & 84 & 88 & 92 & 96 & 97 \\
\hline SME re:al & 300 & .41 .7 & 55.5 & -3.4 & 736 & $7 \therefore 7$ \\
\hline $5-9$ & 178 & $3: 7$ & 45 & -3.4 & 123 & 65.6 \\
\hline $10-.9$ & 274 & 42.1 & 56.1 & -4.1 & 71.6 & 74.1 \\
\hline $20-49$ & 386 & 50.0 & $6 \div 3$ & $: 2.3$ & 77.6 & 78.2 \\
\hline $50-90$ & $>12$ & 52.9 & $9 \% .7$ & 4.9 & 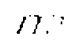 & $82 . y$ \\
\hline $100-199$ & 利 8 & $s 0.9$ & 54.2 & 1.1 & 13.9 & 78.1 \\
\hline 2000 & 30.2 & $1 / 4.4$ & 40.9 & $\because 8$ & 776 & 93.2 \\
\hline
\end{tabular}

Soure: Klobs. Ihe Carrent sratus of the s.Mt:

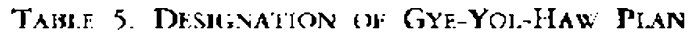

\begin{tabular}{l|rr|rrrr|rr|r}
\hline & 80 & 85 & 90 & 95 & 96 & 97 & 98 & 99 \\
\hline Sicitor & 6 & 40 & $4:$ & 36 & 36 & 36 & 24 & 24 \\
Produits & 1 & 1236 & 1256 & 2053 & 1053 & 1053 & 838 & 836 \\
\hline
\end{tabular}

Sotire: KFSB. The Curtht S:atus of :ne SMEs

The develowment of the salbonatracting struc:ure since the 1980s is chatacterized by a pyranid and multilayer sticturc. In tie 1970s, ila reative imponance of sctecontrating anoug the SMFs decreased, and instead suleortracting berween the SMFs and the IFs begar to increas. Howewer, since the 1080s, sulxomtracting, among the SMEs accelerated. As Table 4 above shows, small- sized enterprises participated in subcontracing. The ratio of SME suxor:tacting has increased since 1980, regardess of the size of firms. This shows that there has been an increased mult layer sibcon- 
tracting relatiurship arang the SME;.

However, the basic chatacteristics of Korcarn subxontracting telatuons have been exploitative, :onconperative, and scrucaly integrated. $\mathrm{Also}$, the customer-supplier relationsip was is"egilar and unstahle. To 1ast:mrionaize a ropperative relationship, the Subcontracting Cooperative Associarion (SCA) was organized. In the beginning, the techrical and financial supsort from ine parent firms centered on the suppliers, who were members of the SCA, but that numbe: gradually decreased.

Alihough the subcortraxing tare has ircreased, it does rot imply an improverisent of trast between the Lis and the Sivis. On the other hand, coliaburation between

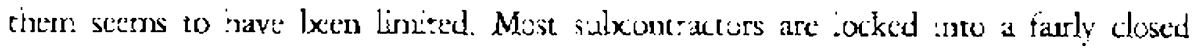
production necwotk camrolled by a particulas lavge assentiler. Sirce the end of the 1980s, she closed producton network has transformed into a more openex ons. The ave:age number of assemblers frem which S.MF. suppliers ase subxonrarted in is 5.9 in 1997. The other side of the coin, however, is that assemble:s increased the number c: suspliers in order to get a secure supply of prociuc:s siace the abour strike cf 1988. This made suppliers compere witi each other, further wearening them..

Ihe subcontranting relations between customers and suppliers retlec: urequal exchange tenns, is: that suppisers lave very linited decision autcoumy irrst :994, 53). The

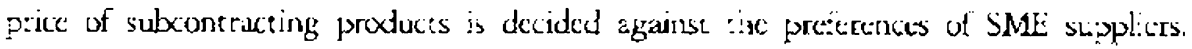
Accoding to ear survey, the peretriage of the cases in which the preferenes of

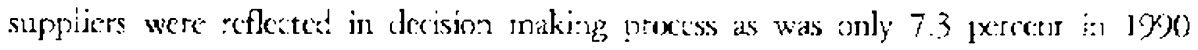
(Baik, ot al. 1995, 4l) and is is believed to still he the case. During economic sxpansion, the subcontracriog price is cecided threuph the ronsu arion of assembles and sippliers. However, during economic downtirn, the price is in most cases cecided by assembiers. This implies that assemblers sufied cloc jurden of costs of economic adjustment on to stippliers.

Deiaying faymer: by assemiles has been cle ma; ur anwarranted business pracolce. In 1997, payreent in casin accounted for 28.2 percem while the remaning 71.8 prercent was paid an cedt, indliding promissory astes. 'Ihis bchavior of celaying

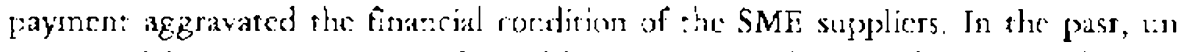
warcanred busizess pratices suth as dolaying paynent by assemblers were the noust importart problems in the sulxontracting relarionship. Bus since the 1980 s, the pressure of low cost has beiome the principle issce in the subontracting relacionship (Table 6). Ir an exclusive relationship witr. parent firms, suppliers are discolraged from having mult:ple customers. Thus, tine sipp.iers are forced to lower their prices. 'I he distribution of profits betweern assernblers and suppliers als becare a eritical issue. Squeezing profit rnargins left no rom for sugyliers to neituvese in technology development (Kerney 19x)5).

The expleitative sulxontacting relaternshy lxiween the IEs and the SMEs rade

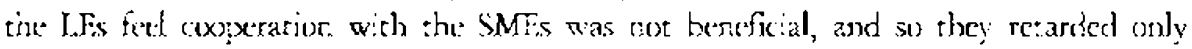
tnust building meas!ure with the SMFx such as stake sharing. For example, aptal investment by the LEs in SMEs supplices coldd increase the level of irust. This inves:ment decreases the possibriliry c: oppor:unistic behavior by assemblers. In 1997 , 
the percentage of capital investment by ine custoness was only 2.8 percent andung the total surveyed firass. Capita: invesmant woild reduce SME's risk in developing rew texhnology for domestic production of parts and componcuts. Onc of the reasons for the I.F's low level of capiral investmeur was the fea: and suspicinn that the SMFs' derision auronomy wou'd ix lessened (Baik, et al.1995).

TABle 6. COMplaints of SLbContract:NG SMES REg.ARE:NG ASsemblexs

\begin{tabular}{|c|c|c|c|c|c|c|}
\hline & 80) & 34: & $\mathbf{8} 8$ & 92 & 96 & 97 \\
\hline Hars\} Qua_:iy Inspectis:n & 3.1 & 126 & 115 & 13.7 & 3). (9 & 33.1 \\
\hline P'ressude: of I.cos Cost & 361 & 3.9 .3 & $16 / 4$ & 38.5 & 68.1 & 61.3 \\
\hline Deluyiug Paymsens & $3^{-1}$ & 2.2 .3 & 18.9 & 231 & i.t. & 52.3 \\
\hline Unstable Order & 11.7 & $: 9.6$ & 137 & 15.3 & 18.3 & $\{1\}$ \\
\hline
\end{tabular}

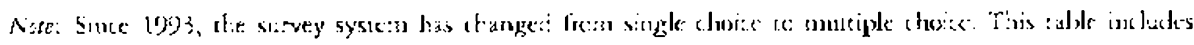
only manifariuring, SMEs.

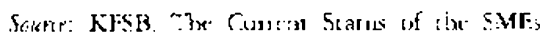

While Enancia' support from cus:omex so suppliers has increased, the level of support is sti.l very ow. The percentage of firancial support to SACE sippliers by customers increased from 4.2 percent in 1987 to 12.7 percent in :99:. Tecbnical assistance nas been regarded as the most important way through which cus:omers and suppliers could enhance comperit:yeness and prociuce vaue-added products. Suppliers complained that they usually receive more tecrno ugical suppert and traing from Japancsc fi:ms than from domestic assemblers (Yoon at al. 1989), 95). Diring the mass producion period, iowevet, cechrical assistance was not a significan: issue. But in the more sophisticated production period, tate production system requires closes coupesanton from design to prexluc:ion lemwen custorrers and supplicrs.

\section{INSTITLTIONS AND TRUST BLILDING}

\section{Causes of the Lack of Irust in Subcontracting Kelations}

Although the subxon:racting retalimsthip has improved recen:ly, it is still baseri on unfar exclange terins aud considered hierarchical and non coxperative. We suggest several reasons for the persistent lack of trist in subcontracting relations.

First, sulxontracting, relatinr.s. has arked enfocing, laws and a sanctioning system. A miniturirg system to regulate the unjust behavior of the assemblens does nor exist. The govemnenr enacted the Monopoly Regulation and Fair Trade Law in 1980, which was designeci to regulare the I.Es' activity anc. to sucd just practices in subcontracting relations. However, the expansion of the LEs did nut s:op and unwarranted business 


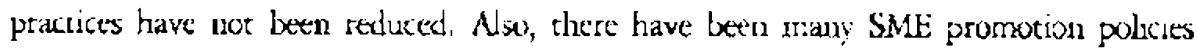

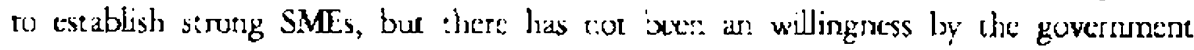
to implement these polices. For example, there was a lack of legal thecks to implement the poling of comprilsory lending to the SMFs in bank loars. Therefore, it had only limited effert. We should ask why these laws have not heen implemented with surcess, which bring us :o the discussion of the next factor

Second, there sas existed a clise political coalition between the government and the LEs. The LEs have been the ma;or coali:tion partners and beneficiaries of many subsidies and privieges. Most SME promotion policies seem to have origitatec in electcral caculations by the government, simply as a lip service. There hes been a lack of willingness anong politcal leacers to seriously impement the SME promotion polices. In thes sense, there was no imterest isatch beiween the govereinerit and the SMEs. We coulc then ask whethet there nay $b_{x}$ ar instituitonal urganuzation for SMlis to pressire the governmen:. This guestion: is related to the third cactor.

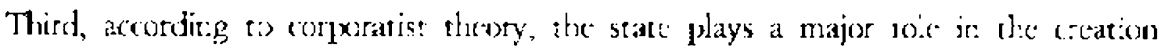
of interese groups, whercas the plualist theory cmphasizes ine woluntary creation of in:erest groups within society. Although the co-Tn:atis" argumen: could nor pencralize across different industrial sectors and over time, the case of the SMF. ir.tesest groups in Ko:ea seems to fit the corpora:ist view. From the corporatist perspective of the Korean state, interes: groups have been mobilized and created by the active rcle of the gover:ment. Interest groups of the SMEs ware ne: essablisheci by the voluntary participation of the SMEs themselves but thruugh the financial assistance of the government. In this caste, tixe organization does not lave appropriaut ins:itutional mecliaisms through whth the peterences of the SMlis can be correctly artculuted and angregated to pressure the gevernment. It roay be hatd to regard the opinio: of the irterest orgarization as the genuine and general interess of the surs.

The Korea Federation st Snall-Medium Business (KrSB) has not functioned wedl erough to acticve their orign:nal pupoxe. In principle, the KFSP was supposed on be run by the mambersin pes provided by the SMEs. However, the government has cortinucd to subsidize tine main budget of the organizarion. Only 10 :ercent of the budget comes from the SME members, 50 percert is subsidized oy the government, ard 40 percent by its business such as rents, the service charge for execuring government procurement po.icy and financial subsidy (Lim :(9)8). 'Therefore, it is hard for the KFSB to bave its own voce on SME policies, ard it is diffic dh to regard the opinions of the organizarion as the voices of the SNELs. Butcause o: its dependence on governument sulsides, the ogganization as an agent has lecome :gncrant of its principal interest, the 5MEs.

Another reasor for the non functioning of the KFSB has to do wiels corraption withir the organizarion. There is a proxurement pxlicy by which the govenmene buys cerrair. produers of the SMFs to guarantece a stable domestic marke. The secuer market provided by the governonent has made SMIIs less competitive and less efficien:. The organization :s more concersed with the distribution of benefiss among pow fuli. firms 
than wint the original punpose of putting pressure on the government. Whereas tixe size of the KFSB is iruct: larger than that of the FKJ (Fidecration of Korcan Industrixs), ar1 LE interest orgarization, the KFSB's activitics have never bern significant enough to compere wirh the FKI's (Park, Mosn-Kyu 1987)

Fourth, the IFs did not regard the SMFs as equal parners for conperation. The main motive for subcontracting came irorr. the low costs of the SMEs. There was ro interest match beeween the LEs and the SMAFs. However, since the late 1980s, the LEs began to realize the fac: that :heir comperitiveness depends on the eficiency of the SMEs. Tc build a high level of efficiency among the SMEs, the cooperative network in subcontracting becomes imporrant, win-kin strategy becomes more important in a technology-driven period.

\section{Trust Building thriugb Institution}

Deakin anc: Wilkizson (1994) developeci a case fo: the propesition that rrust and lag are rompatible, and tha: the lareer may con:ribute on developing and streagthening the former. Iegal regulation is onrceptualized as seing part of a scxietial institutional framework. In a serse, building law's and monito:ing systems is recessany to building the general level of rnus: in subcontracting re.ations in Korea. To build a monitoring system, the government should also realize the importance of the development of SMEs fo: turthe: economic development, and show a strong pilligness to implement and check SME promorion polkes anc re $e_{\varepsilon}$ elatior policies for cooperative subcontracting réaticns. Also, political insisutions through whis tine SMEs coulc lx stiengthened ined to be establishod.

Another framework is reated to the positve: incentive system This includes the permine match of interest betwee: rhe IFs and the SMEs. In a more sophistirated and comperitive economy, ine network basci on thist berween firms beromes more inporiant in compecing internationally. Thercfore, the IFs need to regard the SMEs as a trustable partne: in order to couperate in technology innovation. Capl:al investment by the I.Es in SME suppliers coulc increase the leve. of trust by making them share incerests, and deirease the poss:bility of opporsunistic betavior by the LE assembles.

Besides, to create trust, the:e should be a change of attitude from tocusing on saieguards against the absse of trus: to th:nkng about enhancess of trast. Truist enharcers may ake the form of customers techncal assistaince to suppliers. In formation sharing is also lixely to endhance trast. Whule law may help jumpstare trast re'ations in busisess, crentually trus has to be built aor only by resorting to law but also through carning by-interacting. The uriliteral provision of information and technical assiscance by cusromers, regardless of whether suppliers reciprocate or not, will pribance tnist. 


\section{CONCLUSION}

The perpose of this stualy was to explese ale affect of trust on exonomic develonmente by focusing on the subcontactinge relations hip be:wec the IEs and the SMT: in Korea. Thrs study adopres the irstimtional view of snust, which srates that tnus: is regarded as a product of institurior. Whereas the cultura. view of tr.sst cannot expiain the transformative process of sconomic growth and dowaturn, the institurional view explains the variation of developnent over :ime, with the variation of trust among acsors ir. the economy. 'lhis siudy regarced the Lati and the SMFs as the main actors and

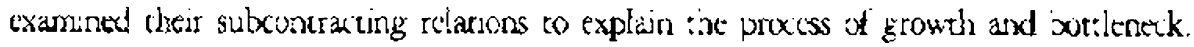

The stijcontracting relations berwcen the Lles and the SMLs in Korta have beens rexpleitative, and nem exope:anive. It is angece that tixe existence of trust letween the I.Fs and the SMEs inciwes innowation and effeciercy. I fowever, during the massproducrion period wher. Kora had a comparative arivarmage is chcap price and low value-added products. the issue of trust may not have ixen a principie issue. Thus, the LEs took advantage of thei: strong position in expioitarive subcontractivg relations and pusied supplier costs dowr. Korea grea fast during this mass-production period under exploitative subcontaacting relations, bue as the capitalist production system tzanstormed from mass production in retlexive manufacturing system, the issue o. crust became tuo:c inportant in aheveng natunal con:parative advantage. The existence of erust between frons reduces trassaction cost and increases itunovation and

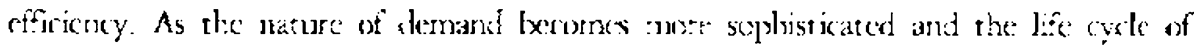
demand s shortenci, the flexibility of firms and rust among firms bxrome necessary. The erent economic bottlenerks can ixe artr:murd to the lack of inus berween the ILEs and the SVIEs. For furhe: economic development, the srevtior. and nain:enance of a gentral level of trust in subcontracting relations is recuired.

'There are mary reasons for the laik of tuust in Korea's subxontracting elarions: thete were 10 :nomtong or sarctio:ing syj:errs in scixcontracting relations; there was no ir:erest match betwern the Llis and tin: SMEs and between the governanent and the SMlis; and tine Kl:S3 as an interest groups fo: SMEs was esiablishoi and eperated sy

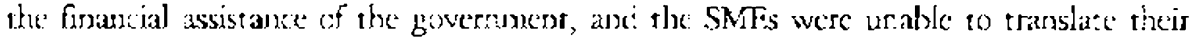
preffereness intes gowernmen: pxolicy

To create and increase the leve of enus: in stbonontracticir relations, a moritoring, and sancrioning systen: needs to be escablishec first. Establishing an instituricual framework requres strong legal enforcement by the government. In order for tire laws to be seriously impiemented, the governmen: srou.d realize that SMEs need to be strengtheneci co overcome the struttual jotteneck of the economy. A'so, a genuine cualition bxtween the government anc the SMEs needs :o be established: the SMles

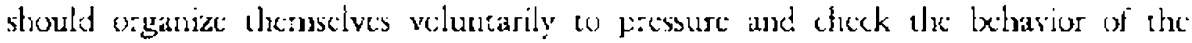
gevernment. The L.Fs sheuld change : heir perspective from short-term intereses solur.g-rerm

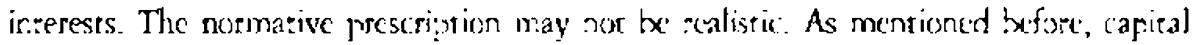
irvestmert by the I.Fs in the SMEs coulc ircrease the level of thist by crearing an 
incentive for $(x)$ jerärjon.

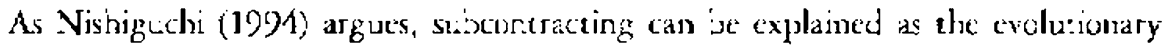
produre of a complex historial inreraction ameng soxicxonomic, technical, and political factors. Tmust could ix increased by the establishmens of instituriona framexorks such as a sanctioning system. However, building institur:ons reçuires mutual interest between the govetnment and socetal actors. An interes: match is calculared not o-2ly by rational choice, but also by a genuine anderstanding of interests.

\section{REIEERENCES}

Arow: K. 1974. The Iimits of Coganization. Now York: Norton.

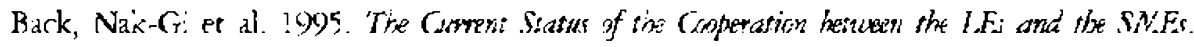
Korea Institute for Inciustrial Eccnorrics and Trade.

Barney, J.B. and Hanser. M. H. 1994. "Trustworthness as a Source cf Comperitive Advartage." Sirutegit Manastemenz Joumai 1s 1/5-40

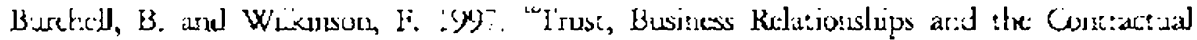

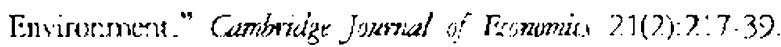

Canang, Ha-Joon. 1993. "The Pelicical Eanomy of Indistrial Policy in Korea." Camimidece Joursal of Fromomic: 17: 131-5;

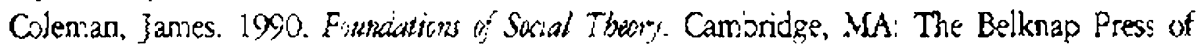
Harvara Linversicy Press.

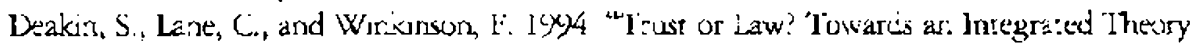

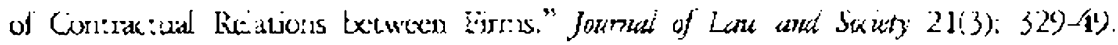

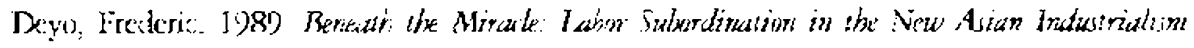
Berkeley: Iniversicy of California Press.

F.rnse Dieter. 1994. "The Korean Electronics Indissery under Pressuse." BRIE Research Pater. Berkeley Roundiab.e cn ti.e Internatiunal Ecunoray.

Evans, Peter, 1505. Embedd:d Autorom;: S:ates and Inciuszral 'Transformation. Princeron: Princeton University Piress.

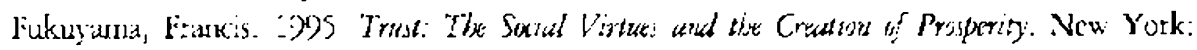
Free: Press

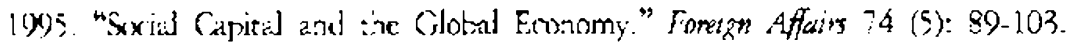
Gamberra, Degc. 1988. "Nafia: The Frice of Discusr." Is Trust: Makins and Breaking Cosperaisur Reluston: ej. D. Gamietta. Oxford: Blackwell.

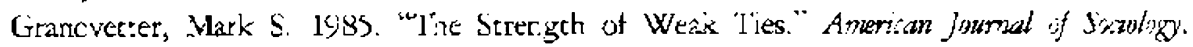
I tami.ton, Gary, 1999. "Asian Busizess Netwcrks in Tlansicion: Wlaat Alan Greenspan

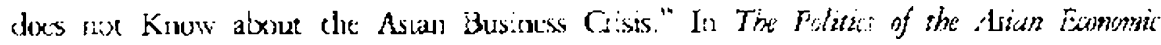

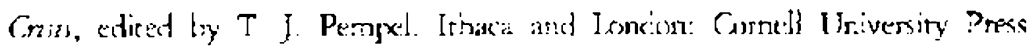

l:ayashi, Nahoke, Elinor Ostrom, James Waiker and Tosnio Yamagishi. 199? "Reciprocity, Trust, and the Illusion of Cocrol A Cross-Sxieral s:ady." Indiina Liniversiry, rorking paxer.

Hong: Jang-Pyo. 1993. "lhe Analysis of Sulxontakering in Korea" (in Korcas), Pl..D. 
1Sissertatioi. Sxoul Soul Nationad Laiversity.

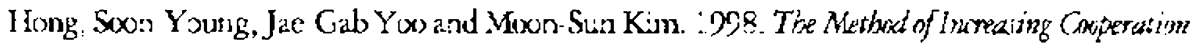

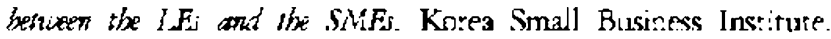

Kenney, Martin. 1995. "Learnirg and Coping with Competitive Pressure: The Korean Electroaics Industry at the Dawn.ag of the 21st Cer:ury." Atsmes. Davis: Linivessity of Caifornia.

Kim, Lun-Mee. 1993. "Contradictons and Limits of a Derelopmentai Statc: With

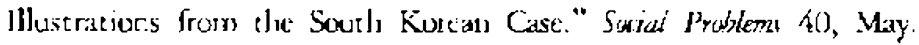

Kim, Yong Hak and Jaesolk Son. 1998. "Trust, Cooperation and Social Riš: A C.ross Cultural Comparison." Korera Jomal 38 (:): 154́n 89 )

Kook, Min-Ho. :\$97. "Econumic Develcpmeat and Confucianis:n in East kssia." Joumal of Korian Sariciogn (in Ko:eas) 3! (Spring).

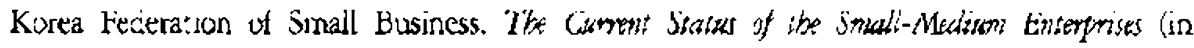
Ko:eari), various issues.

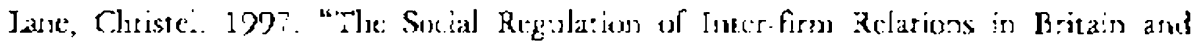
Germany: Market Rules, Iegal Norms, and Tecinnical Stanciands." Cambordye Jounzul of Fronomicr, 2)(2;: 197-216.

Lane and Bacimarn, R 1997. "Cooperation in Inier-tirm Rejations in Britain and Germany:

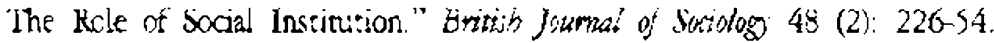

latue, Chrstei anci Reinhard Bactunam. 19y8. Trast Within and Betueten Ongamizations. New York. Oxford Univessioy Press

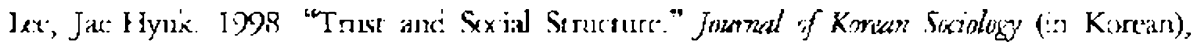
Summer:

lew, Seok-Choon. 1997. "The Opsortunisies and linits of Confucian Capital:sm." Tradizon and Modem (is. Korean), Summer.

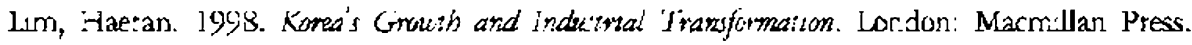
¿999. "Induserial Transtormation anci lisonomic Crisis in Korea asid Taiwan:

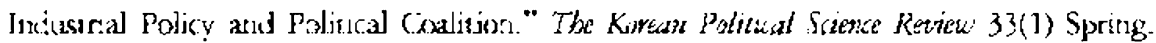

Joren, F H. 1988. "Neither Frienc's ner Strangers: Intormal Nerwarks of Sulwonratring

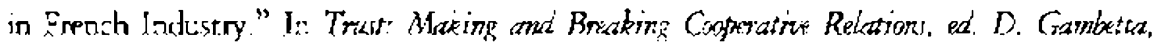
Oxford: Blackutll. :94-210.

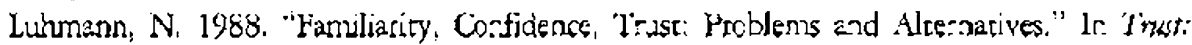

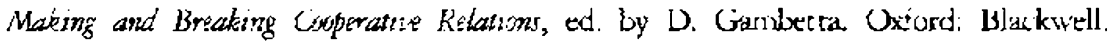

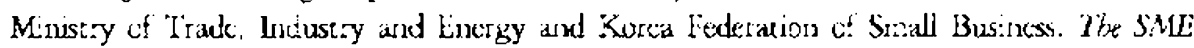
Promotion Prokn, various issues. Serul: MilE and KFSB.

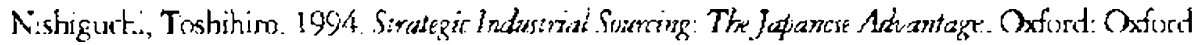
Universiry Press.

Onis, Zjya. 1991. "The Logic of the Developmental S:ate." Comparative Pulitics 24, Oxtober. Park, Moon-Kyu. 196\%. "Interest Representation in Sout'1 Kerea: 'lhe Limits of Corponatist Contro.". Asian Sierw, 2:. Aingus:.

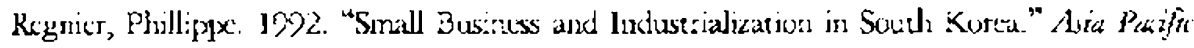
Jnemat of Heandegement $x(1$;

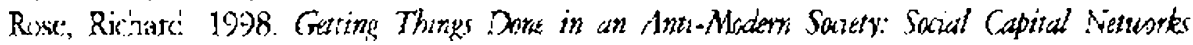
in Russm, Studies in Public Policy Number 304. Scotland: Centre Sor the Stucy of Public 
Poircy.

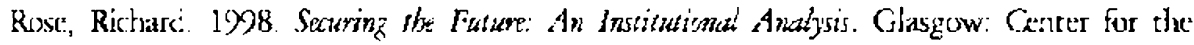
Sr:dy of Public Policy.

Sako, M. 1998. "Dxes Trust Imprcve Business Perforriance?" In Trusi wisbin ana betueen Orxumizations. Eds. Christei Lane and Reininarc Bachmann. New York Onford Liniversity Press.

Shafer, D. Michaiel. :9\%, "Secrors, States, and Social Forces; Kores and Lamba Contront

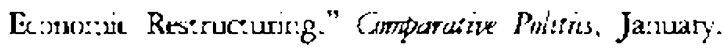

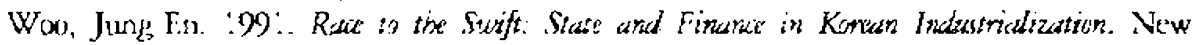
York: Columbia Lniviciry Press.

Yamagishi, T. 1988 "The Provision of a Sanctioning System in the United States and Japan." Sicide Pysholezy Cularienty S1: 265-71.

Yamagishi, I'oshio, Karen S. Ciok anc Morok: Watabx. :998. "Uncentainty, Insst and

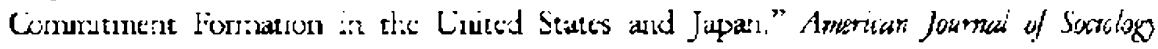
Iú, March.

Yoor, Cinang Bun and Jin Gi Horeg. :989. The Comparative Linciysies of the Subiontratting Structire of the Flectrania Industry betwen Kores and Japan: The Contumer Electronics. (in Kotea-). Seoul: Korea lastitinte for Eccromics and Technology. 